\title{
A Pilot School Meal Program Using Local Foods with Soybean in Rural Bangladesh: Effects on the Nutritional Status of Children
}

\author{
Nobuko Murayama1, Mieko Magami², Salima Akter ${ }^{3}$, Israt Ara Hossain ${ }^{4}$, Liaquat Ali", \\ Mahmud Hossain Faruquees, Sk Akhtar Ahmad5 \\ ${ }^{1}$ Department of Health and Nutrition, University of Niigata Prefecture, Niigata, Japan \\ ${ }^{2}$ General Incorporated Association, Fair Trade Roshun, Tokyo, Japan \\ ${ }^{3}$ Department of Medical Biotechnology, Bangladesh University of Health Sciences, Dhaka, Bangladesh \\ ${ }^{4}$ Department of Biochemistry and Cell Biology, Bangladesh University of Health Sciences, Dhaka, Bangladesh \\ ${ }^{5}$ Department of Occupational \& Environmental Health, University of Health Sciences, Dhaka, Bangladesh \\ Email: murayama@unii.ac.jp
}

How to cite this paper: Murayama, N., Magami, M., Akter, S., Hossain, I.A., Ali, L., Faruquee, M.H. and Ahmad, S.A. (2018) A Pilot School Meal Program Using Local Foods with Soybean in Rural Bangladesh: Effects on the Nutritional Status of Children. Food and Nutrition Sciences, 9, 290-313.

https://doi.org/10.4236/fns.2018.94023

Received: March 24, 2018

Accepted: April 23, 2018

Published: April 26, 2018

Copyright (C) 2018 by authors and Scientific Research Publishing Inc. This work is licensed under the Creative Commons Attribution International License (CC BY 4.0).

http://creativecommons.org/licenses/by/4.0/

\begin{abstract}
Background: Growth retardation is a challenge in Bangladesh. School feeding programs with fortified biscuits have been evaluated in Bangladesh. However, the impacts of a school meal program using local foods on the growth and nutritional status of children have not been investigated. Objective: To determine whether a school meal program (SMP) using local foods with soybean could improve children's growth and micronutrient status in rural Bangladesh. Methods. Two primary schools were randomly assigned as intervention (SMP; $\mathrm{n}=200$ ) and control (non-SMP; $\mathrm{n}=200$ ) schools. Children in the intervention school were supplied a school meal with local foods including soybean, containing more than one-third of the recommended daily allowance of energy and nutrients, 5 days/week for 8 months. The attendance rate and school lunch consumption of the children were monitored. Baseline and final anthropometry, hemoglobin and micronutrient status were assessed. Results. There were no significant differences in anthropometric measurements at baseline between the intervention and control groups, but there were differences in the prevalence of anemia, vitamin A deficiency and zinc deficiency. After the intervention, children in the SMP school showed a larger degree of improvement in the height-for-age $\mathrm{Z}$-score $(\mathrm{P}<0.001)$, red blood cell count $(\mathrm{P}=0.001)$ and hemoglobin concentration $(\mathrm{P}<0.001)$ than children in the non-SMP school. However, there were no positive effects on the body mass index (BMI)-for-age Z-score, serum ferritin, serum retinol or serum zinc status among children in the SMP school. Conclusion: A school meal program using local foods with soybean improved the height velocity and hemoglobin
\end{abstract}


concentration of children in rural Bangladesh.

\section{Keywords}

School Meal Program, Local Food, Child Growth, Anemia, Bangladesh

\section{Introduction}

Growth retardation, which includes stunting, wasting, underweight and micronutrient deficiency, continues to be a major public health problem in most low-income countries. Growth retardation and micronutrient deficiency contribute to mortality, morbidity, reduced immune competence and impaired cognitive function and productivity [1] [2] [3]. Growth retardation is generally caused by protein-energy malnutrition, and an estimated one-third of children under the age of 5 worldwide (178 million) are stunted, with 112 million underweight [4]. A short maternal stature increases the risk of small-for-gestational-age newborn and preterm birth [5]. The four most common forms of micronutrient malnutrition are iron, vitamin A, iodine and zinc [4]. Iron deficiency, the most common micronutrient deficiency in the world, causes anemia, which is a risk factor for maternal death and impaired physical and cognitive development and suboptimal immune systems in children [6]. Vitamin A deficiency, the second-most common micronutrient deficiency, is associated with an increased rate and severity of infectious diseases and is a primary cause of childhood morbidity and mortality, blindness in children and anemia [6] [7].

A number of trials of supplements for pregnant women and children under 5 years of age have been performed [8] [9] [10] [11]. However, fewer studies have been conducted in school-age children. Two main types of studies of the effect of school meals on the nutritional status of children have been performed. The first type includes studies of the effects of micronutrient fortification of school meals using seasoning powder. Such studies have been conducted in India [12] [13], Thailand [14] [15] [16], Indonesia [17], the Philippines [18], Himalayan villages [19] and Bangladesh [20]. Fortification interventions include trials of a micronutrient-fortified beverage in Tanzania [21] and Botswana [22], and micronutrient-fortified biscuits in South Africa [23], Vietnam [24] [25] and Haiti [26]. All of these studies suggested that such micronutrient fortifications improve micronutrient levels and short-term cognitive function. These approaches are suitable for high-risk areas/groups of school children but are not practical and not sustainable for all school children in developing countries.

The second type of study involves the effects of school meals. School meals made with local food are sustainable, and nutritionally appropriate school meals can be used to provide nutrition education to children and their families. They can even be an incentive for children to attend school and can activate the local food economy. However, few studies on the effects of school meals on the nutri- 
tional status of children have been reported. In Jamaica, the provision of a school breakfast benefited children's school attendance, achievements and nutritional status, including height, weight and body mass index (BMI) [27] [28]. A community-based school snack was provided by the Indonesian government from 1996 to 1998. Its effects on the attendance rate of children, selection of nutritious foods by parents and community members, and benefit for the local economy via the use of local foods were reported, but no effects on nutritional status were reported [29]. A small-scale study in Indonesia found that school meals improved hemoglobin and hematocrit levels and body mass index [30], and a large-scale study in Pakistan found a decreased percentage of children with wasting [31], but no comparisons were made with controls. In Malawian children, school feeding was associated with an improvement in reversal learning and catch-up growth in lean muscle mass but not in height and weight [32]. Some studies used local foods, which contain nutrients showing shortages in children in low-income countries. In Burkina Faso, a randomized controlled intervention trial found a positive impact of the addition of red palm oil, a local food, to school meals on vitamin A status but not on anthropometry [33]. Many studies have been conducted in Kenya. An intake of micronutrients high in animal-derived foods was associated with better growth in rural Kenyan school children [34]. In addition, nutrient intake and nutritional status were better among participant pupils of a parent-supported school lunch program in Kenya compared with nonparticipant pupils [35]. Food supplements had a positive impact on weight gain, and the addition of animal-sourced foods increased the lean body mass of school children in Kenya [36], with meat supplementation also increasing arm muscle area [37]. A cluster randomized controlled feeding intervention showed beneficial effects of school snacks using meat, milk and vitamin A-fortified oil on morbidity [38] and school test scores [39].

A review of the effects of school meals indicated relatively consistent positive effects of school feeding on energy intake, micronutrient status, school enrollment and child attendance. However, their impact on growth, cognition and the academic achievements of school children is less clear [40] [41]. More evidence of the effects of school meals with local food on growth should be obtained.

Protein energy and micronutrient deficiency are serious public health problems in Bangladesh. The prevalence of stunting (height-for-age Z-score $<-2$ ), wasting (BMI-for-age Z-score $<-2$ ) and underweight (weight-for-age Z-score < -2 ) among children have been reported for under 5 years of age [42] and for 6 to 9 years of age [43]. Anemia is common among all age groups and in both sexes [44] [45] [46]. Subclinical vitamin A deficiency among preschool and school children has been reported [46] [47]. One of the causes of growth retardation and anemia is poor macro- and micronutrient intake. The daily intakes of energy per head for children aged 7 to 9 years and 10 to 12 years in 1995-1996 were $1504 \mathrm{kcal}$ (males) and $1314 \mathrm{kcal}$ (females) and $1788 \mathrm{kcal}$ (males) and $1639 \mathrm{kcal}$ (females), respectively [43]. The average protein intake in children aged 7 to 9 
years in 1995-1996 was lower than required, at $37 \mathrm{~g}$ (males) and $33 \mathrm{~g}$ (females) [39]. Further data show that $20 \%-40 \%$ of school children (aged 5 - 10 years) take less protein than required [48]. For adults, vitamin A deficiency is highly prevalent among rural pregnant women [49] [50]. The high prevalence of inadequate micronutrient intake has been shown by food balance sheets for Bangladesh [51]. The very poor micronutrient intake of preschool children and women is explained by both a low food intake and limited diversity [52].

Based on the previous data and higher primary school enrollment rate, at $93 \%$ for males and 97\% for females in 2010-2014 [53], a school meal program with local foods would be a reasonable approach in Bangladesh. School feeding programs with fortified biscuits have been evaluated in Bangladesh [48] [54]. However, the impacts of a school meal program using local foods on the growth and nutritional status of children has not been investigated. We focused on protein, iron, zinc and vitamin A because these nutrients are particularly important for growth and anemia prevention, both of which are serious public health problems in Bangladesh, as mentioned above. To increase the amount and quality (amino acid variety) of protein and the amount of iron and zinc, we used soybean because the typical diet in Bangladesh is based on cereal, which can lead to inadequate protein consumption because of poor digestibility and limited amounts of lysine [55]. Many kinds of beans are used in Bangladesh, and soybean can easily be introduced into the local diet. Soybean is easy to grow, rich in lysine and can compensate for the shortage of lysine in rice. In addition, dried soybean can be preserved without refrigeration, which is important because many villages in Bangladesh lack electricity. To increase the amount of vitamin A, we also used local green leafy vegetables.

Thus, the objective of this study was to assess the impact of a school meal program with local foods containing soybean on the growth and micronutrient status of school children in rural Bangladesh.

\section{Methods}

\subsection{Study Sites and Participants}

The study was conducted in the Sharsha sub-district of the Jessore district, located in the southwestern region of Bangladesh bordered by India. A non-governmental organization, the Japan-Bangladesh Cultural Exchange Association (JBCEA), has been conducting an income-generating and lifestyle-improving program in this area. This study was a collaboration of the authors and the JBCEA.

Two government schools were selected according to the following criteria. We selected six areas in the Sharsha sub-district that were not beside the main road to avoid the bias of the introduction of new external food/information during the intervention. A sample size of 95 children per group was calculated based on an estimated difference in hemoglobin concentration at the end of the study of 4 $\mathrm{g} / \mathrm{L}$ with an estimated standard deviation (SD) of $9 \mathrm{~g} / \mathrm{L}$, significance level 
(two-tailed test) of $5 \%$ and power of $80 \%$, with an additional $20 \%$ allowance for dropouts. One school with approximately 200 students (100 male and $100 \mathrm{fe}-$ male) was selected from each of the six areas. We measured all children's weight and height in the six schools and selected two of these schools without differences in the mean weight and height.

One school was randomly allocated as the intervention school, which was supplied the school meal (SMP school), and the other was the comparison school, which was not supplied the school meal (non-SMP school). The non-SMP school planned to introduce a school meal in the next year, and they agreed to join this study. There were 211 (98 males and 113 females) and 200 (111 males and 89 females) children registered in the SMP and non-SMP schools, respectively (Figure 1). All parents of the students were contacted and consented to their child's participation in the study. We excluded 13 children from each school who did not attend the baseline examination, as well as 2 children from the SMP school and 1 child from the non-SMP school who were not 5 to 13 years old. Thus, 193 children in the SMP school and 186 children in the non-SMP school were enrolled in the study. In addition, 20 children in the SMP school and 4 children in the non-SMP school did not attend the final examination. Accordingly, 172 children (78 males and 94 females) and 182 children (103 males and 79 females) completed the study in the SMP and non-SMP schools, respectively. The children who dropped out did not differ from the remaining children in any background characteristics or nutritional status. The schools have five classes corresponding with grades 1 through 5 . The school year starts in January. The school management committee cooperated with this study.

\subsection{Research Design}

The baseline survey was conducted on February 17th and 18th, 2010. The school meal was served from March 1st, 2010 to November 8th, 2010. The end line survey was conducted on November 9th and 10th, 2010.

Children in the SMP school received the school meal at lunch time every day that they attended school. There were 253 days during the intervention period and 127 school days in the SMP school after excluding Fridays, Saturdays and holidays. There were 152 school days in the non-SMP school. The JBCEA staff checked the quality and quantity of the school meals at least once per week.

We created two kinds of meals based on the local menu that was popular in the village. One was "Kichuri", which is boiled rice porridge with vegetables, soybean and spices; the other was curry and boiled rice with soybean. The same ingredients were used in the two menus. The school meal ingredients are shown in Table 1. To make the school meal system sustainable, all foods were locally available at low cost. The average total cost including the cost of food, cooking fuel and payment for cooks per meal per child was 21.5 taka (this includes 15.4 taka for food), or approximately US $\$ 0.3$. 


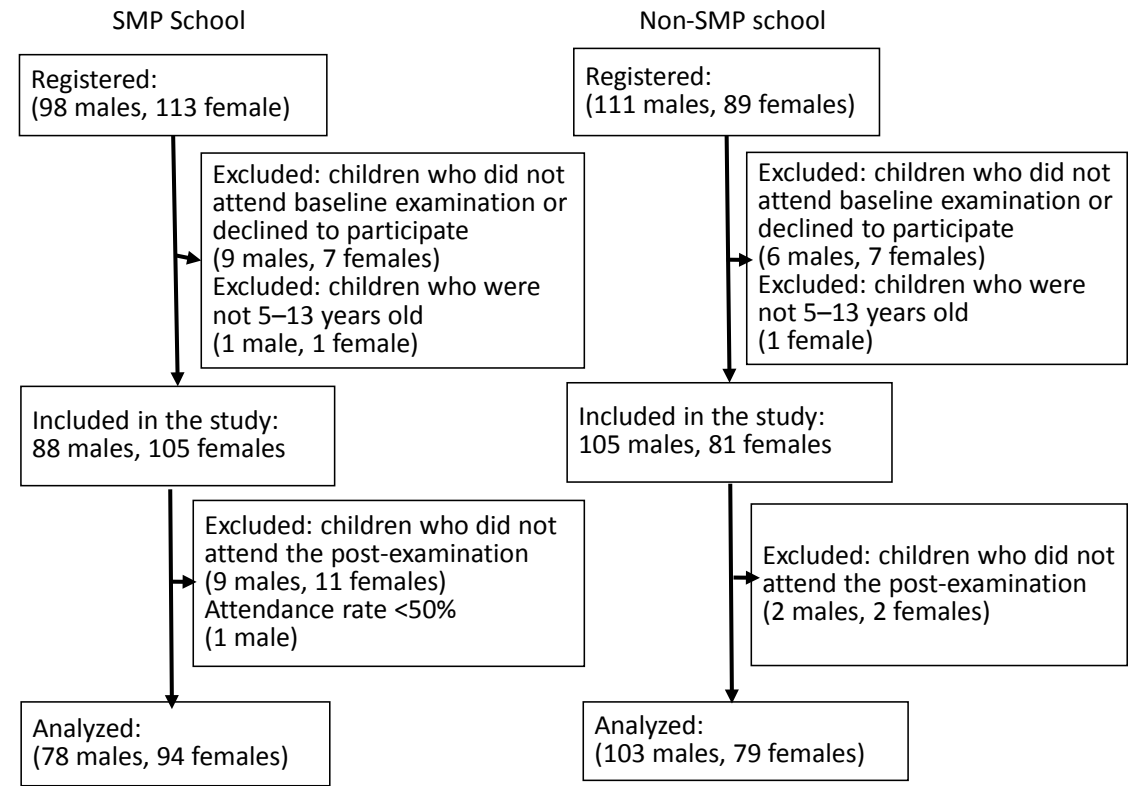

Figure 1. Trial profile.

Table 1. Amount of school meal ingredients per meal per child.

\begin{tabular}{ccc}
\hline Food stuff & $\begin{array}{c}\text { Class } 1 \text { and } 2^{\mathrm{a}} \\
(\mathrm{g})\end{array}$ & $\begin{array}{c}\text { Class } 3-5^{\mathrm{b}} \\
(\mathrm{g})\end{array}$ \\
\hline Rice & 41.5 & 50 \\
Soybean & 34.5 & 42 \\
Onion & 16.6 & 20 \\
Garlic & 8.3 & 10 \\
Chili & 2.9 & 3.5 \\
Ginger & 3.3 & 4 \\
Potato & 41.5 & 50 \\
Papaya & 41.5 & 50 \\
Pumpkin & 83.5 & 100 \\
Amaranthus tricolor & 49.8 & 60 \\
(Joseph's coat) & & \\
Vegetable oil & 11.6 & 14 \\
Salt & 3.5 & 4.2 \\
Garam masala & 0.4 & 1 \\
Turmeric & 0.7 & 1 \\
Cumin & 0.8 & 1 \\
\hline
\end{tabular}

${ }^{\mathrm{a} C l a s s} 1$ and 2: 5 - 8 years old; ${ }^{\mathrm{b} C l a s s} 3$ - 5: 9 - 13 years old.

Before the school meal program was started, the nutrient values of the school meal and locally produced soybean were analyzed in Japan (Japan Food Research Laboratories) in August 2009. The energy and nutrient requirements for Bangladeshi children and the energy and nutrient contents of the school meal and soybean per person are shown in Table 2. The school meal supplied one-third of the daily energy and riboflavin requirements and more than two-thirds of the daily requirements for other nutrients based on the Recommended Dietary Allowances (RDAs) for Bangladeshi people [56]. Almost the same daily amounts of amino acids, based on a WHO report [55], were supplied 
Table 2. Energy and nutrient requirements and composition of the school meal supplied at the SMP school.

\begin{tabular}{|c|c|c|c|c|c|c|c|c|c|}
\hline \multirow[b]{2}{*}{ Table Head } & \multicolumn{5}{|c|}{ Classes 1 and 2 ( 5 - 8 years old $)$} & \multicolumn{4}{|c|}{ Classes 3 - 5 ( 9 - 3 years old $)$} \\
\hline & & $\begin{array}{l}\mathrm{RDA} \\
/ \text { day }^{\mathrm{a}}\end{array}$ & $\begin{array}{c}\text { Supplied } \\
\text { by } \\
\text { school } \\
\text { meal }^{\mathrm{b}}\end{array}$ & $\begin{array}{c}\text { Supplied } \\
\text { by } \\
\text { soybean }^{c}\end{array}$ & $\begin{array}{c}\% \\
\mathrm{RDA}^{\mathrm{d}}\end{array}$ & RDA/day & $\begin{array}{c}\text { Supplied } \\
\text { by school } \\
\text { meal }^{\mathrm{b}}\end{array}$ & $\begin{array}{l}\text { Supplied } \\
\text { by } \\
\text { soybean }^{c}\end{array}$ & $\begin{array}{c}\% \\
\mathrm{RDA}^{\mathrm{d}}\end{array}$ \\
\hline Energy & kcal & 1820 & 631 & 136 & 35 & 2190 & 761 & 157 & 35 \\
\hline Protein & g & 31.0 & 27.7 & 12.3 & 89 & 38.0 & 33.4 & 14.2 & 88 \\
\hline Fat & g & - & 21.7 & 6.8 & & - & 26.2 & 7.9 & \\
\hline Carbohydrate & g & - & 91.5 & 9.2 & & - & 110.3 & 10.7 & \\
\hline Sodium & $\mathrm{mg}$ & - & 1850 & 0 & & - & 2229 & 0 & \\
\hline Potassium & $\mathrm{mg}$ & - & 1702 & 535 & & - & 2051 & 620 & \\
\hline Calcium & $\mathrm{mg}$ & 450 & 296 & 69 & 66 & 450 & 357 & 80 & 79 \\
\hline Iron & $\mathrm{mg}$ & 10.0 & 9.0 & 1.9 & 90 & 10.0 & 10.0 & 2.2 & 100 \\
\hline Zinc & $\mathrm{mg}$ & - & 2.6 & 1.2 & & - & 3.2 & 1.4 & \\
\hline Vitamin A & $\mu \mathrm{g} \mathrm{RE}$ & 300 & 328 & 0.0 & 109 & 400 & 395 & 0 & 99 \\
\hline Thiamine & $\mathrm{mg}$ & 0.90 & 0.70 & 0.2 & 78 & 1.20 & 0.85 & 0.26 & 71 \\
\hline Riboflavin & $\mathrm{mg}$ & 1.00 & 0.30 & 0.1 & 30 & 1.20 & 0.37 & 0.09 & 31 \\
\hline Folate & $\mu \mathrm{g}$ & 100 & 152 & 0 & 152 & 100 & 183 & 0 & 183 \\
\hline Vitamin C & $\mathrm{mg}$ & 20 & 33 & 0 & 165 & 20 & 40 & 0 & 200 \\
\hline Fiber & g & - & 19.1 & 5.8 & & - & 23.1 & 6.7 & \\
\hline \multicolumn{10}{|l|}{ Amino acids } \\
\hline Isoleucine & $\mathrm{mg}$ & 961 & 1131 & 587 & 118 & 1178 & 1363 & 680 & 116 \\
\hline Leucine & $\mathrm{mg}$ & 1891 & 1197 & 1011 & 63 & 2318 & 2406 & 1172 & 104 \\
\hline Lysine & $\mathrm{mg}$ & 1488 & 1523 & 838 & 102 & 1824 & 1836 & 972 & 101 \\
\hline $\begin{array}{l}\text { Sulfur amino } \\
\text { acids }\end{array}$ & $\mathrm{mg}$ & 744 & 846 & 380 & 114 & 912 & 1019 & 440 & 112 \\
\hline Methionine & $\mathrm{mg}$ & - & 407 & 179 & & - & 490 & 208 & \\
\hline Cysteine & $\mathrm{mg}$ & - & 439 & 200 & & - & 530 & 232 & \\
\hline $\begin{array}{c}\text { Aromatic } \\
\text { amino acids }\end{array}$ & $\mathrm{mg}$ & 1271 & 2418 & 1321 & 190 & 1558 & 2913 & 1532 & 187 \\
\hline Phenylalanine & $\mathrm{mg}$ & - & 1373 & 687 & & - & 1654 & 796 & \\
\hline Tyrosine & $\mathrm{mg}$ & - & 1045 & 459 & & - & 1259 & 532 & \\
\hline Threonine & $\mathrm{mg}$ & 775 & 1071 & 545 & 138 & 950 & 1291 & 632 & 136 \\
\hline Tryptophan & $\mathrm{mg}$ & 205 & 373 & 176 & 182 & 251 & 449 & 204 & 179 \\
\hline Valine & $\mathrm{mg}$ & 1240 & 1353 & 624 & 109 & 1520 & 1630 & 724 & 107 \\
\hline Histidine & $\mathrm{mg}$ & 496 & 715 & 362 & 144 & 608 & 861 & 420 & 142 \\
\hline Arginine & $\mathrm{mg}$ & - & 2081 & 980 & & - & 2507 & 1136 & \\
\hline Alanine & $\mathrm{mg}$ & - & 1326 & 583 & & - & 1598 & 676 & \\
\hline Asparagine & $\mathrm{mg}$ & - & 3371 & 1577 & & - & 4061 & 1828 & \\
\hline Glutamine & $\mathrm{mg}$ & - & 5101 & 2498 & & - & 6146 & 2896 & \\
\hline Glycine & $\mathrm{mg}$ & - & 1211 & 587 & & - & 1460 & 680 & \\
\hline Proline & $\mathrm{mg}$ & - & 1339 & 697 & & - & 1613 & 808 & \\
\hline Serine & $\mathrm{mg}$ & - & 1427 & 704 & & - & 1719 & 816 & \\
\hline
\end{tabular}

${ }^{\mathrm{a}}$ Recommended dietary allowances (RDA) for Bangladesh children 4 - 6 years old and 7 - 9 years old (Institute of Nutrition \& Food Science, University of Dhaka, 1992) were adopted for the RDAs of energy and nutrients for class 1 - 2 and class $3-5$, respectively. - ; RDA is not available. Amino acids (mg) = Amino acid scoring pattern ( $\mathrm{mg} / \mathrm{g}$ protein requirement) for children $3-10$ years old ${ }^{*}$ protein requirement $(\mathrm{g} /$ day) for each age group. Protein and amino acid requirements were taken from Human Nutrition, a report from a joint WHO/FAO/UNU expert consultation, from the WHO technical report series 935, 2007. ${ }^{\text {EEnergy and }}$ nutrients supplied by the school meal were analyzed in Japan Food Research Laboratories. 'Soybean grown in the study village was analyzed in Japan Food Research Laboratories. Sulfur-containing amino acids = methionine and cysteine; Aromatic amino acids = phenylalanine and tyrosine. ${ }^{\mathrm{d}} \% \mathrm{RDA}=$ amount of nutrients supplied by the school meal/RDA* 100 . 
by the meal. The serving size of the school meal was different for classes 1 and 2 ( 5 - 8 years of age) and classes 3 through 5 ( 9 - 13 years of age) due to the differences in their RDAs. The nutrient contents of the school meal and \% RDA are shown in Table 2.

Before the school meal program was started, we prepared the following: 1) a manual for school meal preparation, which included information on hygienic food preparation, cooking equipment, table wear, hand washing, order of foods, cooking methods and weighing and serving of meals; 2)training for chefs, the JBCEA employed and trained five chefs from the community for 5 days (3 days for hygiene and 2 days for cooking and serving), and four practice simulations involving meal cooking and serving were performed before the study began; and 3) cooking environment; as such, a kitchen and dining room were built at the school, and the water was tested to prevent arsenic contamination.

Regarding the time and place of the school meal, children in classes 1 and 2 had the meal from 12:15 to 13:15 in the classroom and went home afterward. Children in classes 3 through 5 had the meal from 11:00 to 12:00 in the dining room. The children in both schools took a tablet for deworming every 6 months. The SMP school children were instructed to wash their hands before eating the school meal.

The estimated school meal consumption was monitored according to the following methods. Teachers recorded the attendance of children every day during the intervention period. To estimate the consumption and calculate the consumption rate for each child, we weighed the serving amount and the leftovers for each child on 3 non-consecutive days in October 2010. The consumption rate was calculated by subtracting the leftover amount from the serving amount and dividing by the serving amount.

\subsection{Data Collection}

Sociodemographic data were collected at baseline only. Anthropometrical data and blood samples were collected from all children at baseline and at the end of the study.

Sociodemographic data were collected in January 2010 at the participants' homes. The staff of this project attended three training sessions of 2 hours each. They interviewed the parents of the children using a questionnaire. The questionnaire assessed household members, parents' education level, religion, household income, area of land owned by the household and number of months of rice shortage. To assess the protein intake levels, parents were asked the frequency of consumption of protein-rich foods (e.g., fish, egg, poultry and meat) of the child.

Anthropometric measurements (height and weight) were obtained by the same well-trained project staff from the JBCEA at baseline and at the end of the intervention period according to the anthropometric standardization reference manual [57]. All measurements were performed in the morning before lunch. 
The height of the children was measured without shoes to the nearest $0.1 \mathrm{~cm}$ by a researcher using a Martin anthropometer. Height was measured twice, and if there was a difference $>0.5 \mathrm{~mm}$, a third measurement was taken. Weight was measured to the nearest $0.05 \mathrm{~kg}$ on a digital scale (InnerScan SOV BC621, TANITA, Tokyo, Japan) with the children wearing light clothes. Anthropometric data were calculated as Z-scores for weight-for-age (WAZ), height-for-age (HAZ) and BMI $\left(\mathrm{kg} / \mathrm{m}^{2}\right)$-for-age (BMIZ), based on the WHO Child Growth Standards for children aged 5 - 19 years [54]. The WAZ was calculated until 120 months of age because the standard was not available for children over 120 months of age.

Biochemical assessment was performed in the Bangladesh Institute of Research and Rehabilitation for Diabetes, Endocrine and Metabolic Disorders (BIRDEM). A non-fasting venous blood of approximately $7-8 \mathrm{~mL}$ was taken in the morning from each child by venipuncture using polypropylene syringes and divided into two tubes. The first tube (containing EDTA) was used for the estimation of hematological parameters including red blood cell (RBC) count, hemoglobin, hematocrit and mean corpuscular volume (MCV). The hematological tests were done on the same day in a certified diagnostic center of Jessore metropolitan city using a CELL-DYN 3200 System (Abbott Laboratories, Abbott Park, IL, USA). The remaining blood $(6 \mathrm{~mL})$ was then ejected into a glass tube for biochemical analysis. The blood sample was allowed to clot for approximately $30 \mathrm{~min}$. The serum was separated from the coagulated blood in the field by a portable, battery-powered centrifuge at $3000 \mathrm{rpm}$ for $30 \mathrm{~min}$. The serum was aliquot into five different Eppendorf tubes with equal amounts of approximately $500 \mu \mathrm{L}$ in each tube; the vitamin A aliquot was collected in duplicate and was covered with aluminum foil due to light sensitivity. All samples were frozen onsite using dry ice and transported to BIRDEM, Dhaka, Bangladesh, where it was preserved at $-56^{\circ} \mathrm{C}$ until analysis. Serum iron, total iron binding capacity (TIBC) and unsaturated iron binding capacity (UIBC) were measured using a bichromatic $(600,700 \mathrm{~nm})$ endpoint technique. Serum ferritin was measured by a one-step enzyme immunoassay. Biochemical parameters were estimated by an automated analyzer (Dimension RxL Max, Siemens Healthcare Diagnostics Inc., USA). Serum retinol determinations were performed with a commercially available vitamin $\mathrm{A}$ and vitamin $\mathrm{E}$ determination kit (Bio-Rad A/E, Bio-Rad Inc., Hercules, CA, USA) by the use of the high-performance liquid chromatography (HPLC) method (Shimadzu, LC, Kyoto, Japan). Serum Zn was measured using a standard procedure involving flame atomic absorption spectrometry, which was modified from the graphite method (Perkin Elmer, AAnalyst 800, Shelton, CT, USA).

The precision of all of the biochemical assays was checked using pooled serum, and their accuracy was established using certified reference materials or appropriate manufacturer controls. The corresponding between-assay CVs of the low-to-high control samples for iron, ferritin, TIBC and UIBC were $4.2 \%$ to $1.8 \%, 7.8 \%$ to $6.5 \%, 2.8 \%$ to $3.97 \%$ and $2.1 \%$ to $2.9 \%$, respectively. To estimate 
serum zinc, zinc standards were prepared by diluting the stock standard solution [5\% (v/v) glycerol]. A 5\% (v/v) glycerol solution was used as a blank solution when determining serum zinc. The between-assay CVs of low and high standards were $14.0 \%$ and $12.5 \%$, respectively. The vitamin A and E quality control material provided by Bio-Rad was used to monitor the accuracy of the laboratory testing procedures for the analytes. The mean value (SD, CV \%) was $81.6 \mu \mathrm{g} / \mathrm{dL}(10.8$, $13.1 \%$ ) compared with the certified value of 78.0 (range 58 - 98) $\mu \mathrm{g} / \mathrm{dL}$.

\subsection{Statistical Analysis}

Stunted growth was defined as HAZ $<-2$ SDs and wasted was defined as BMIZ $<-2$ SDs of the WHO standards [58]. Anemia was defined as a hemoglobin concentration $<115 \mathrm{~g} / \mathrm{L}$ for children aged $6-11$ years and $<120 \mathrm{~g} / \mathrm{L}$ for children aged 12 years and older [59]. A low MCV was defined as an MCV $<80 \mathrm{fL}$, and plasma ferritin concentrations $<20 \mu \mathrm{g} / \mathrm{L}$ were defined as depleted [59]. Subclinical vitamin A deficiency was defined as a plasma retinol concentration $<0.70$ $\mu \mathrm{mol} / \mathrm{L}$ [60]. Zinc deficiency was defined as serum $\mathrm{Zn}<0.65 \mathrm{mg} / \mathrm{L}$ for children $<$ 10 years, $\mathrm{Zn}<0.66$ for female subjects $\geq 10$ years and $\mathrm{Zn}<0.70 \mathrm{mg} / \mathrm{L}$ for male subjects $\geq 10$ years $[61]$.

Statistical analyses were performed using SPSS software (Windows, version 21.0). Differences in sociodemographic characteristics and the prevalence of undernutrition at baseline between children in the SMP and non-SMP schools were tested using chi-square and t-tests (two-tailed). Differences in baseline data between children in the SMP and non-SMP schools were examined using t-tests (two-tailed). Differences in changes in the data from baseline to endline between children in the SMP and non-SMP schools were examined by ANCOVA, adjusted for sex, age and value at baseline. Differences were considered significant at $\mathrm{P}<0.05$.

The study was conducted according to the guidelines laid down in the Declaration of Helsinki, and all procedures involving human subjects were approved by the ethics committee of the Niigata University of Health and Welfare, Japan (No. 17155-100106), and the National Research Ethics Committee of Bangladesh in Medical Research Council (BMRC/NREC/2007-2010/147). The staff of this study visited all students' houses to explain the school meal and study protocol to the parents. Parents were invited to an information meeting at the schools. Written informed consent was obtained from all subjects' parents. Permission from the Jessore District, Sharsha sub-district, communities and schools were obtained via meetings. This trial was also approved by the Government of the People's Republic of Bangladesh, Office of the Primary Education Section 2 (memo no. PraShia/Pori: and Dev:/25/2010/62).

\section{Results}

\subsection{Characteristics of Participants at Baseline and Attendance Rate/Consumption Rate during the Program}

The sociodemographic characteristics at baseline are shown in Table 3. There 
were no significant differences in sociodemographic status between the SMP and non-SMP school-children except for the ratio of males, area of household land and frequency of fish consumption. The ratio of male children was lower in the SMP school (45.3\%) than in the non-SMP school (56.6\%). The mean (standard error) ages of children in the SMP and non-SMP schools were 106.5 (1.8) months and 108.3 (1.8) months, respectively. The SMP school households owned a smaller area of land than non-SMP school households. Most of the children did not eat fish, egg, poultry or meat every day. The frequency of fish consumption was higher in children in the SMP school than in the non-SMP school.

The nutritional status of the children at baseline is shown in Table 4. Stunted growth was seen in $19.2 \%$ and $23.3 \%$ of males and $28.7 \%$ and $32.9 \%$ of females in the SMP and non-SMP schools, respectively. Wasting was found in $23.1 \%$ and $23.3 \%$ of males and $22.3 \%$ and $19.0 \%$ of females in the SMP and non-SMP schools, respectively. There were no significant differences between the SMP and non-SMP schools in terms of stunting and wasting prevalence at baseline. At baseline, anemia prevalence was significantly higher in the SMP school compared to non-SMP school, $83.3 \%$ vs $70.9 \%$ ( $p<0.001$ ), for males and $95.7 \%$ vs $81.0 \%$ ( $\mathrm{p}<0.01$ ) for females, respectively. The prevalence of depleted iron stores was very low. Males in the SMP school showed a significantly lower prevalence of subclinical vitamin A deficiency and a higher prevalence of zinc deficiency than males in the non-SMP school.

The median (25th, 75th percentile) attendance rates at the SMP and non-SMP schools were $81.1 \%(74.8 \%, 87.2 \%)$ and $96.7 \%$ (93.4\%, 98.0\%), respectively. The median (25th, 75th percentile) consumption rate of the school meal at the SMP school was $78.6 \%(59.0 \%, 100.0 \%)$, and we estimated that the consumption rate was approximately $80 \%$.

\subsection{Effects of the School Meal on Anthropometric Outcomes}

The anthropometric outcomes are shown in Table 5. There were no significant differences in anthropometric indicators at baseline between the SMP and non-SMP schools. After 8 months, children in the SMP school showed greater increases in height and HAZ than children in the non-SMP school, both males and females. The mean (standard error) changes in height and HAZ of children in SMP vs non-SMP schools were $3.8(0.1) \mathrm{cm}$ vs $3.3(0.1) \mathrm{cm}(\mathrm{P}<0.001)$ and $0.03(0.01)$ vs $-0.04(0.01)(\mathrm{P}<0.001)$, respectively. There were no differences in mean changes in weight, BMI, WAZ or BMIZ.

\subsection{Effects of the School Meal on Biochemistry Outcomes}

The biochemical outcomes are shown in Table 6. There were significant differences in baseline data between the SMP and non-SMP schools for hemoglobin, UIBC, serum retinol and serum zinc. Children in the SMP school had lower levels of hemoglobin and serum zinc and higher levels of UIBC and serum retinol 
Table 3. Baseline sociodemographic characteristics of the participants.

\begin{tabular}{|c|c|c|c|c|}
\hline Variables & & $\begin{array}{c}\text { SMP } \\
(\mathrm{n}=172)\end{array}$ & $\begin{array}{l}\text { Non-SMP } \\
(\mathrm{n}=182)\end{array}$ & $p$-value \\
\hline $\begin{array}{c}\text { Sex (\%) } \\
\text { Age at baseline (months) }\end{array}$ & $\begin{array}{c}\text { Male } \\
\text { mean }(\mathrm{SE})\end{array}$ & $\begin{array}{c}45.3 \\
106.5(1.8) \\
\left(\mathrm{n}=170^{\mathrm{a}}\right)\end{array}$ & $\begin{array}{c}56.6 \\
108.3(1.8) \\
\left(\mathrm{n}=181^{\mathrm{a}}\right)\end{array}$ & $\begin{array}{c}0.043 \\
0.48\end{array}$ \\
\hline $\begin{array}{l}\text { Number of family } \\
\text { members (\%) }\end{array}$ & $\begin{array}{l}3-4 \text { persons } \\
5-6 \text { persons } \\
7 \text { - persons }\end{array}$ & $\begin{array}{l}45.3 \\
41.2 \\
13.5\end{array}$ & $\begin{array}{l}41.4 \\
43.6 \\
14.9\end{array}$ & 0.76 \\
\hline $\begin{array}{c}\text { Number of children at } \\
\text { home (\%) }\end{array}$ & $\begin{array}{l}1 \text { - } 2 \text { children } \\
3 \text { - } 4 \text { children } \\
5 \text { - children }\end{array}$ & $\begin{array}{c}52.4 \\
41.8 \\
5.9\end{array}$ & $\begin{array}{c}54.7 \\
38.1 \\
7.2\end{array}$ & 0.74 \\
\hline $\begin{array}{l}\text { Birth order of the subject } \\
\text { child (\%) }\end{array}$ & $\begin{array}{l}\text { 1st child } \\
\text { 2nd child } \\
\text { 3rd child }\end{array}$ & $\begin{array}{l}41.2 \\
28.2 \\
30.6\end{array}$ & $\begin{array}{l}39.8 \\
35.4 \\
24.9\end{array}$ & 0.29 \\
\hline $\begin{array}{l}\text { Education level of father } \\
(\%)\end{array}$ & $\begin{array}{c}\text { No education } \\
\text { Primary school } \\
\text { Secondary school } \\
\text { High school and higher }\end{array}$ & $\begin{array}{r}46.5 \\
31.2 \\
12.9 \\
9.4\end{array}$ & $\begin{array}{c}44.8 \\
38.1 \\
10.5 \\
6.6\end{array}$ & 0.46 \\
\hline $\begin{array}{l}\text { Education level of mother } \\
\qquad(\%)\end{array}$ & $\begin{array}{c}\text { No education } \\
\text { Primary school } \\
\text { Secondary school } \\
\text { High school and higher }\end{array}$ & $\begin{array}{c}31.2 \\
44.1 \\
18.8 \\
5.9\end{array}$ & $\begin{array}{c}32.0 \\
39.2 \\
23.2 \\
5.5\end{array}$ & 0.72 \\
\hline $\begin{array}{c}\text { Household income per } \\
\text { month (\%) }\end{array}$ & $\begin{array}{c}\text { Low income }(0 \text { - } 2500 \text { taka }) \\
\text { Middle income }(2501-3000 \text { taka }) \\
\text { High income (3001 - taka) }\end{array}$ & $\begin{array}{l}34.1 \\
32.4 \\
33.5\end{array}$ & $\begin{array}{l}35.9 \\
36.5 \\
27.6\end{array}$ & 0.47 \\
\hline Own land (\%) & $\begin{array}{l}0 \text { - } 14 \text { katha } \\
15 \text { - } 43 \text { katha } \\
45 \text { - } 600 \text { katha }\end{array}$ & $\begin{array}{l}47.1 \\
21.2 \\
31.8\end{array}$ & $\begin{array}{l}33.1 \\
31.5 \\
35.4\end{array}$ & 0.017 \\
\hline $\begin{array}{c}\text { Number of months of rice } \\
\text { shortage during the last } \\
\text { year }(\%)\end{array}$ & $\begin{array}{l}0-1 \text { month/year } \\
2-5 \text { months/year } \\
6 \text { months/year }\end{array}$ & $\begin{array}{l}34.1 \\
21.2 \\
44.7\end{array}$ & $\begin{array}{l}35.9 \\
22.7 \\
41.4\end{array}$ & 0.82 \\
\hline $\begin{array}{c}\text { Frequency of fish } \\
\text { consumption for the child } \\
(\%)\end{array}$ & $\begin{array}{c}\text { Every day } \\
3 \text { - 6/week } \\
1-2 / \text { week } \\
<1 / \text { week }\end{array}$ & $\begin{array}{l}23.8 \\
21.4 \\
38.1 \\
16.7\end{array}$ & $\begin{array}{l}13.5 \\
20.2 \\
51.7 \\
14.6\end{array}$ & 0.032 \\
\hline $\begin{array}{c}\text { Frequency of egg } \\
\text { consumption for the child } \\
(\%)\end{array}$ & $\begin{array}{c}\text { Every day } \\
3-6 / \text { week } \\
1-2 / \text { week } \\
<1 / \text { week }\end{array}$ & $\begin{array}{c}2.4 \\
6.5 \\
51.2 \\
40.0\end{array}$ & $\begin{array}{c}1.1 \\
5.5 \\
55.2 \\
38.1\end{array}$ & 0.73 \\
\hline $\begin{array}{l}\text { Frequency of poultry or } \\
\text { meat consumption for the } \\
\text { child (\%) }\end{array}$ & $\begin{array}{c}\text { Every day } \\
3 \text { - 6/week } \\
1-2 / \text { week } \\
<1 / \text { week }\end{array}$ & $\begin{array}{c}0.6 \\
0.0 \\
8.2 \\
91.2\end{array}$ & $\begin{array}{c}0.0 \\
0.6 \\
9.9 \\
89.5\end{array}$ & 0.51 \\
\hline $\begin{array}{c}\text { Frequency of diarrhea (\%) } \\
\text { Frequency of fever }(\%)\end{array}$ & $\begin{array}{l}\text { More than once/month } \\
\text { More than once/month }\end{array}$ & $\begin{array}{l}2.4 \\
8.2\end{array}$ & $\begin{array}{l}1.7 \\
5.6\end{array}$ & $\begin{array}{l}0.72 \\
0.59\end{array}$ \\
\hline
\end{tabular}

SE: standard error, 1 taka $=0.01537$ USD, 1 katha $=720$ square feet $\left(67 \mathrm{~m}^{2}\right)$. ${ }^{\text {a }}$ Number of respondents to the questionnaire. ${ }^{\mathrm{b}} p$-value for chi-square test between children in the SMP and non-SMP schools except age at baseline. $p$-value for Mann-Whitney U-test between children in the SMP and non-SMP schools for age at baseline. 
Table 4. Prevalence of undernutrition at baseline.

\begin{tabular}{|c|c|c|c|c|c|c|}
\hline \multirow[b]{2}{*}{ Variables } & \multicolumn{3}{|c|}{ Male } & \multicolumn{3}{|c|}{ Female } \\
\hline & $\begin{array}{c}\text { SMP } \\
(\mathrm{n}=78) \\
\%\end{array}$ & $\begin{array}{c}\text { Non-SMP } \\
(\mathrm{n}=103) \\
\%\end{array}$ & $p$-value ${ }^{\mathrm{a}}$ & $\begin{array}{c}\text { SMP } \\
(\mathrm{n}=94) \\
\%\end{array}$ & $\begin{array}{c}\text { Non-SMP } \\
(\mathrm{n}=79) \\
\%\end{array}$ & $p$-value $^{\mathrm{a}}$ \\
\hline Stunted (\%) & 19.2 & 23.3 & 1.00 & 28.7 & 32.9 & 0.25 \\
\hline Wasted (\%) & 23.1 & 23.3 & 0.22 & 22.3 & 19.0 & 0.29 \\
\hline Anemia (\%) & 83.3 & 70.9 & $<0.001$ & 95.7 & 81.0 & 0.006 \\
\hline Depleted iron stores (\%) & 0.0 & 1.9 & 0.51 & 1.1 & 6.3 & 0.09 \\
\hline $\begin{array}{c}\text { Subclinical vitamin A } \\
\text { deficiency (\%) }\end{array}$ & 3.8 & 16.5 & 0.008 & 13.8 & 19.0 & 0.41 \\
\hline Zinc deficiency (\%) & 35.9 & 13.6 & 0.001 & 26.6 & 19.0 & 0.28 \\
\hline
\end{tabular}

${ }^{a} p$-value for chi-square test between children in the SMP and non-SMP schools. Stunted was defined as a height-for-age Z-score $<-2$ SDs of the WHO standards median. Wasted was defined as a BMI-for-age Z score $<-2$ SDs of the WHO standards median. Anemia was defined as hemoglobin $(\mathrm{Hb})<115 \mathrm{~g} / \mathrm{L}$ for boys and girls $<12$ years old and $\mathrm{Hb}<120 \mathrm{~g} / \mathrm{L}$ for boys and girls $\geq 12$ years old. Depleted iron stores were defined as serum ferritin $<15 \mu \mathrm{g} / \mathrm{L}$ in boys and girls of all ages. Subclinical vitamin A deficiency was defined as serum retinol $<0.7 \mu \mathrm{mol} / \mathrm{L}(20 \mu \mathrm{g} / \mathrm{dL})$ in boys and girls of all ages. Zinc deficiency was defined as serum $\mathrm{Zn}<0.65 \mathrm{mg} / \mathrm{L}$ for children $<10$ years old, $<0.66 \mathrm{mg} / \mathrm{L}$ for girls $\geq 10$ years old, and $<0.70 \mathrm{mg} / \mathrm{L}$ for boys $\geq$ 10 years old.

Table 5. Anthropometric status of participants at baseline and endline and the change between baseline and endline.

\begin{tabular}{|c|c|c|c|c|c|c|c|}
\hline \multirow[t]{2}{*}{ Variables } & \multirow[t]{2}{*}{ Time } & \multicolumn{2}{|c|}{$\begin{array}{c}\text { SMP } \\
(\mathrm{n}=172)\end{array}$} & \multicolumn{2}{|c|}{$\begin{array}{l}\text { Non-SMP } \\
(\mathrm{n}=182)\end{array}$} & \multirow[t]{2}{*}{$p$-value } & \multirow[t]{2}{*}{$p$-value ${ }^{\mathrm{b}}$} \\
\hline & & mean & SE & mean & SE & & \\
\hline \multirow[t]{3}{*}{ Height $(\mathrm{cm})$} & Baseline & 124.3 & 0.7 & 124.0 & 0.8 & 0.76 & \\
\hline & Endline & 128.1 & 0.8 & 127.2 & 0.8 & & \\
\hline & Change & 3.8 & 0.1 & 3.3 & 0.1 & $<0.001$ & $<0.001$ \\
\hline \multirow[t]{3}{*}{ Weight (kg) } & Baseline & 22.5 & 0.4 & 22.3 & 0.4 & 0.76 & \\
\hline & Endline & 24.1 & 0.4 & 23.8 & 0.4 & & \\
\hline & Change & 1.7 & 0.1 & 1.5 & 0.1 & 0.07 & 0.15 \\
\hline \multirow[t]{3}{*}{ BMI $\left(\mathrm{kg} / \mathrm{m}^{2}\right)$} & Baseline & 14.3 & 0.1 & 14.3 & 0.1 & 0.90 & \\
\hline & Endline & 14.5 & 0.1 & 14.5 & 0.1 & & \\
\hline & Change & 0.2 & 0.0 & 0.2 & 0.0 & 0.94 & 0.74 \\
\hline Height-for-age & Baseline & -1.2 & 0.08 & -1.40 & 0.08 & 0.07 & \\
\hline \multirow[t]{2}{*}{ Z-score } & Endline & -1.2 & 0.08 & -1.50 & 0.08 & & \\
\hline & Change & 0.03 & 0.01 & -0.04 & 0.01 & $<0.001$ & $<0.001$ \\
\hline Weight-for-age & Baseline & -1.30 & 0.09 & -1.50 & 0.08 & 0.12 & \\
\hline \multirow[t]{2}{*}{ Z-score ${ }^{c}$} & Endline & -1.20 & 0.08 & -1.40 & 0.08 & & \\
\hline & Change & 0.12 & 0.03 & 0.11 & 0.03 & 0.81 & 0.11 \\
\hline BMI-for-age & Baseline & -1.30 & 0.07 & -1.30 & 0.06 & 0.68 & \\
\hline \multirow[t]{2}{*}{ Z-score } & Endline & -1.30 & 0.07 & -1.30 & 0.06 & & \\
\hline & Change & 0.01 & 0.03 & -0.01 & 0.02 & 0.74 & 0.92 \\
\hline
\end{tabular}

SE: standard error. ${ }^{a} p$-value for t-test between children in the SMP and non-SMP schools. ${ }^{b} p$-value for ANCOVA adjusted for sex, age and value at baseline between children in the SMP and non-SMP schools. 'The numbers of participants in the SMP and non-SMP schools were 159 and 157, respectively, because WHO reference data is not available for children younger than 10 years old. Z-scores were based on WHO Child Growth Standards for children 5 - 19 years old (2007). 
Table 6. Micronutrient status of participants at baseline and endline and the change between baseline and endline.

\begin{tabular}{|c|c|c|c|c|c|c|c|}
\hline \multirow[t]{2}{*}{ Variables } & \multirow[t]{2}{*}{ Time } & \multicolumn{2}{|c|}{$\begin{array}{c}\text { SMP } \\
(\mathrm{n}=172)\end{array}$} & \multicolumn{2}{|c|}{$\begin{array}{r}\text { Non-SMP } \\
(\mathrm{n}=182)\end{array}$} & \multirow[t]{2}{*}{$p$-value ${ }^{\mathrm{a}}$} & \multirow[t]{2}{*}{$p$-value } \\
\hline & & mean & SE & mean & SE & & \\
\hline \multirow[t]{3}{*}{ Hemoglobin (g/L) } & Baseline & 10.7 & 0.0 & 11.0 & 0.1 & $<0.001$ & \\
\hline & Endline & 10.6 & 0.1 & 10.5 & 0.1 & & \\
\hline & Change & 0.0 & 0.1 & -0.5 & 0.1 & $<0.001$ & $<0.001$ \\
\hline \multirow[t]{3}{*}{ Hematocrit (\%) } & Baseline & 32.5 & 0.2 & 32.1 & 0.4 & 0.38 & \\
\hline & Endline & 34.7 & 0.2 & 34.6 & 0.3 & & \\
\hline & Change & 2.3 & 0.2 & 2.6 & 0.4 & 0.51 & 0.80 \\
\hline \multirow{3}{*}{$\begin{array}{l}\text { Serum ferritin } \\
\qquad(\mu \mathrm{g} / \mathrm{L})\end{array}$} & Baseline & 60.5 & 2.5 & 55.2 & 1.9 & 0.09 & \\
\hline & Endline & 69.3 & 2.7 & 64.7 & 1.9 & & \\
\hline & Change & 8.8 & 2.9 & 9.4 & 1.9 & 0.86 & 0.45 \\
\hline \multirow{3}{*}{$\begin{array}{l}\text { Serum iron } \\
(\mu \mathrm{mol} / \mathrm{L})\end{array}$} & Baseline & 11.1 & 0.3 & 11.8 & 0.3 & 0.10 & \\
\hline & Endline & 15.2 & 0.3 & 14.9 & 0.3 & & \\
\hline & Change & 4.1 & 0.3 & 3.1 & 0.4 & 0.048 & 0.21 \\
\hline \multirow{3}{*}{$\begin{array}{l}\text { Red blood cell } \\
\qquad(\mathrm{RBC}) \\
(\text { million} / \mu \mathrm{L})\end{array}$} & Baseline & 4.0 & 0.0 & 3.9 & 0.0 & 0.23 & \\
\hline & Endline & 4.1 & 0.0 & 4.0 & 0.0 & & \\
\hline & Change & 0.2 & 0.0 & 0.1 & 0.0 & 0.042 & 0.001 \\
\hline \multirow{3}{*}{$\begin{array}{l}\text { Mean cell volume } \\
\quad(\mathrm{MCV})(\mathrm{f} / \mathrm{L})\end{array}$} & Baseline & 82.3 & 0.4 & 81.4 & 0.4 & 0.10 & \\
\hline & Endline & 84.8 & 0.5 & 86.5 & 0.4 & & \\
\hline & Change & 2.5 & 0.3 & 5.1 & 0.3 & $<0.001$ & $<0.001$ \\
\hline \multirow{3}{*}{$\begin{array}{l}\text { Unsaturated iron } \\
\text { binding capacity } \\
(\mathrm{UIBC})(\mu \mathrm{mol} / \mathrm{L})\end{array}$} & Baseline & 54.5 & 0.9 & 52.2 & 0.7 & 0.041 & \\
\hline & Endline & 50.5 & 0.9 & 47.9 & 0.8 & & \\
\hline & Change & -4.0 & 1.3 & -4.3 & 0.9 & 0.85 & 0.02 \\
\hline \multirow{3}{*}{$\begin{array}{l}\text { Total iron-binding } \\
\text { capacity (TIBC) } \\
(\mu \mathrm{mol} / \mathrm{L})\end{array}$} & Baseline & 65.0 & 1.0 & 63.6 & 0.6 & 0.22 & \\
\hline & Endline & 63.3 & 0.7 & 63.1 & 0.7 & & \\
\hline & Change & -1.7 & 1.1 & -0.5 & 0.8 & 0.39 & 0.95 \\
\hline \multirow{3}{*}{$\begin{array}{c}\text { Transferrin } \\
\text { saturation (\%) }\end{array}$} & Baseline & 17.9 & 0.7 & 18.8 & 0.4 & 0.22 & \\
\hline & Endline & 24.5 & 0.6 & 24.1 & 0.6 & & \\
\hline & Change & 6.7 & 0.7 & 5.2 & 0.6 & 0.13 & 0.34 \\
\hline \multirow{3}{*}{$\begin{array}{l}\text { Serum retinol } \\
\qquad(\mu \mathrm{g} / \mathrm{dL})\end{array}$} & Baseline & 37.6 & 1.3 & 31.8 & 1.0 & 0.001 & \\
\hline & Endline & 41.6 & 1.5 & 36.3 & 0.7 & & \\
\hline & Change & 4.0 & 1.7 & 4.5 & 1.2 & 0.83 & 0.02 \\
\hline \multirow[t]{3}{*}{ Serum zinc (mg/L) } & Baseline & 0.9 & 0.03 & 1.1 & 0.04 & $<0.001$ & \\
\hline & Endline & 1.2 & 0.04 & 1.4 & 0.04 & & \\
\hline & Change & 0.3 & 0.03 & 0.3 & 0.04 & 0.30 & 0.69 \\
\hline
\end{tabular}


ANCOVA adjusted for sex, age and value at baseline between children in the SMP and non-SMP schools.

than children in the non-SMP school. After 8 months, children in the SMP school showed significantly larger amount of changes of hemoglobin and RBC levels than children in the non-SMP school. The mean (standard error) changes in hemoglobin and RBC levels of children in SMP vs non-SMP schools were 0.0 $(0.1) \mathrm{g} / \mathrm{L}$ vs $-0.5(0.1) \mathrm{g} / \mathrm{L}(\mathrm{P}<0.001)$ and $0.2(0.0)$ vs $0.1(0.0)(\mathrm{P}=0.001)$, re- 
spectively. In contrast, the changes in MCV $(\mathrm{P}<0.001)$, UIBC $(\mathrm{P}=0.02)$ and serum retinol $(P=0.02)$ were smaller in the children in the SMP school than in the children in the non-SMP school. There were no differences in the amount of change between the two schools for other indicators, such as hematocrit, serum ferritin, serum iron, TIBC, transferrin saturation and serum zinc.

There were no significant changes in the prevalence of stunting, wasting, anemia, depleted iron stores, subclinical vitamin A deficiency or zinc deficiency (data not shown).

\section{Discussion}

This study investigated whether the administration of a community-based school meal containing local foods and soybean over a period of 8 months could improve the physical growth and micronutrient status of school children. To our knowledge, this is the first study to use soybean and local foods without any fortification in a school meal program and to evaluate their impact compared with a control group. Children who participated in the school meal program showed significant improvements in height velocity, HAZ and hemoglobin concentration compared with nonparticipating children. These findings stress the importance of an adequate protein and amino acid composition of school meals in low-income countries where there is a low availability of animal protein foods.

Energy and nutrient intakes from the school meal in this study were estimated. The school meal supplied about one-third (33\%) of the energy and riboflavin needs, more than two-thirds (66\%) of other nutrients and almost the correct amounts of amino acids according to the daily requirements. Children consumed $80 \%$ of the supplied school meal per day. Among a total of 253 days during the intervention period, there were 127 school days, meaning that the school meal was only supplied on $50 \%$ of days. The estimated average requirement intake per day during the intervention period was $13 \%$ of energy and riboflavin, $26 \%$ of other nutrients and $40 \%$ of amino acids. Thus, we need to consider the number of school days when planning an effective school meal program.

At baseline, the rates of stunting and wasting were $20 \%-30 \%$ and $20 \%$, respectively. In previous studies, the prevalence of stunting in 2011 and 2014 was $41 \%$ and $16 \%$, the prevalence of wasting in the same years was $36 \%$ and $14 \%$, respectively, among children under 5 years of age [42]. In 1995-1996, the prevalence of stunting and wasting among children aged 6 to 9 years was 54.8\% (males) and $50.1 \%$ (females) and $17.7 \%$ (males) and $19.1 \%$ (females), respectively [43]. Another study reported that the rates of stunting and wasting were approximately $20 \%$ and $30 \%$, respectively, in 2008 [20]. The baseline anthropometric status of this study was thus similar to that of previous work.

The soybean-based school meal improved the linear growth of children with a statistically significant change in height velocity and HAZ, but not in BMIZ. The results are comparable to those of a previous one-year intervention study in Bangladesh school children using micronutrient-fortified yogurt [20]. However, there is little evidence on the effects of school meals on anthropometry out- 
comes. Studies from Jamaica [27] and Malawi [32] showed no effects of school meals on weight and height, whereas a study from Indonesia and Pakistan showed an effect on recovery from wasting [30] [31]. Height gain during the school feeding intervention period, using milk or meat, was positively predicted by the average daily intake of energy from animal foods, iron, calcium, vitamin $A$ and vitamin $B_{12}$ among Kenyan school children [34]. However, a review reported that the positive impact of school feeding on growth was less conclusive [40].

There are some possible reasons for these results. One reason is the effects of micronutrients. A systematic review noted that the effects of micronutrients on growth were equivocal [62]. A meta-analysis of the effects of micronutrients on the growth of children found that multi-micronutrient interventions did improve child growth [63]. Another possible reason is protein quality and quantity. Additional dietary protein, mainly from soybean, increases tissue deposition for growth and provides an important anabolic drive for linear bone growth in this study. Several intervention studies with additional protein-rich foods suggested a similar specific stimulatory effect of protein on linear bone growth mediated through IGF-1 [55]. In the current study, serum retinol and serum zinc levels were not improved in the children in the SMP school. Thus, it is reasonable to assume that the height gain during the school feeding intervention period using soybean was positively predicted by protein quantity and quality. Further research into the mediator between protein nutritional status and growth, such as IGF-1 and growth hormone, is needed to confirm this assumption.

The prevalence of anemia at baseline was $80 \%-95 \%$ in the SMP school and $70 \%-80 \%$ in the non-SMP school, showing a significant difference. In previous studies, the prevalence of anemia in preschool children, school children and pregnant women was $50 \%-60 \%, 30 \%-40 \%$ and $40 \%-50 \%$, respectively, from 2001 to 2004 [44] [45]. The prevalence of anemia in school children in 2008 was $53 \%, 16$ and in 2011-2012, it was 19\% [46]. The anemia prevalence in this study was thus higher than that of previous studies. However, the prevalence of depleted iron stores was very low. A high prevalence of anemia without depleted iron stores was observed in previous studies [20] [64] [65]. A high level of iron in groundwater could be one of the reasons for the higher iron status [64] [65]. The low hemoglobin concentration is explained by the low intake of animal foods and vitamin A [66] [67], and multiple micronutrient fortifications of food or supplementation enhanced the hemoglobin status in Bangladesh [68] [69]. Children in the non-SMP school showed a hemoglobin concentration decrease of $-0.5 \mathrm{~g} / \mathrm{L}$ during the intervention period, but the hemoglobin concentration of the SMP school children did not change; the difference in the changes between the groups was significant. One of the possible reasons for the decrease in the hemoglobin concentration among non-SMP school children might be an increased need for hemoglobin mass during rapid growth [60]. The SMP school children showed no change in hemoglobin concentration because the school meal compensated for the increased need for nutrients to increase hemoglobin 
mass according to growth. The significant differences in the hemoglobin concentration change and RBC count between SMP and non-SMP school children, without a difference in serum iron status, suggests better utilization of iron, which may have been due to the presence of multiple micronutrients in the soybean school meal, as suggested by previous intervention studies [13] [14] [19] [20] [21] [23] [24] [25] [68] [69]. Another possible reason is the increased quality and quantity of the protein from the soybean school meal in the SMP school children. Protein quality and quantity, especially histidine, are important for maintaining the hemoglobin concentration [70].

The prevalence of subclinical vitamin A deficiency at baseline was less than $20 \%$. The prevalence of zinc deficiency ranged from $13 \%$ to $36 \%$. In previous studies, the rates of subclinical vitamin A deficiency among preschool children and school children were $56 \%$ and 3\% - 4\%, respectively, in the 1990s [47], and both were 21\% in 2011-2012 [46]. The baseline nutritional status of vitamin A in this study was similar to that of previous studies. There was no previous data for zinc deficiency among children in Bangladesh. There were no positive effects of the school meal on serum retinol or zinc concentrations, possibly due to the relatively higher serum retinol and zinc concentrations at baseline and an insufficient amount in the meal to cause significant changes during the intervention period.

There are some limitations in this study. First, the baseline data of nutritional biomarkers in blood differed between intervention and non-intervention children because we ethically could not take blood before sampling the schools. Second, infection can influence biomedical indicators, but we did not measure C-reactive protein levels or monitor morbidity. Third, this study was conducted only for one intervention school and one non-intervention school in one area of rural Bangladesh.

Even with these limitations, the findings of this study suggest that school meals containing a certain amount of amino acids improve height velocity in school children in low-income countries. Not only iron but also protein may play important roles in maintaining hemoglobin concentrations. Thus, both micronutrients and the amount and quality of protein should be considered when providing school meals in low-income countries.

Two directions of further study are recommended. One is a large-scale, population-based study. Another is a study to investigate the mechanisms of the effects of a school meal with soybean on growth and the quality and quantity of protein required for appropriate human growth.

\section{Conclusion}

Children who participated in a community-based school meal program using local foods with soybean showed significant improvements in height velocity and hemoglobin concentration compared with children who did not participate in the school meal program. These findings support the positive effects of school meal program with local foods which contain adequate nutrients on improving 
nutritional status of children in low-income countries where high prevalence of undernutrition.

\section{Acknowledgements}

We thank the participants and their families for their contribution to this study. We thank Hitomi Sato and Osamu Kushida for their cooperation with this field research. We are also greatly indebted to the primary schools and the Board of Education in Bangladesh.

Nobuko Murayama. designed the research; Nobuko Murayama, Mieko Magami, Mahmud Hossain Faruquee, and Sk Akhter Ahmad conducted the field research; Nobuko Murayama, Salima Akter, Israt Ara Hossain and Liaquat Ali analyzed the data; and Nobuko Murayama, Mieko Magami and Salima Akter wrote the paper. All authors approved the submitted version.

This research was supported by a research grant [grant number H21B02, H22B04] from the Niigata University of Health and Welfare. The funders had no role in the design, analysis or writing of this article. The authors declare no conflicts of interest.

\section{References}

[1] Bryce, J., Boschi-Pinto, C., Shibuya, K. and Black, R.E. (2005) WHO Estimates of the Causes of Death in Children. The Lancet, 365, 1147-1152. https://doi.org/10.1016/S0140-6736(05)71877-8

[2] Black, R.E., Allen, L.H., Bhutta, Z.A., Caulfield, L.E., de Onis, M., Ezzati, M., et al. (2008) Maternal and Child Undernutrition: Global and Regional Exposures and Health Consequences. The Lancet, 371, 243-260. https://doi.org/10.1016/S0140-6736(07)61690-0

[3] Black, R.E., Victora, C.G., Walker, S.P., Bhutta, Z.A., Cristian P., de Onis, M., et al. (2013) Maternal and Child Undernutrition and Overweight in Low-Income and Middle-Income Countries. The Lancet, 382, 427-451. https://doi.org/10.1016/S0140-6736(13)60937-X

[4] Ahmed, T., Hossain, M. and Sanin, K.I. (2012) Global Burden of Maternal and Child Undernutrition and Micronutrient Deficiencies. Annals of Nutrition and Metabolism, 61, 8-17. https://doi.org/10.1159/000345165

[5] Kozuki, N., Katz, J., Lee, A.C.C., Vogel, J.P., Silveira, M.F., Sania, A., et al. (2015) Short Maternal Stature Increases Risk of Small-for-Gestational-Age and Preterm Births in Low- and Middle-Income Countries: Individual Participant Data Meta-Analysis and Population Attributable Fraction. The Journal of Nutrition, 145, 2542-2550. https://doi.org/10.3945/jn.115.216374

[6] Bailey, R.L., West Jr., K.P. and Black, R.E. (2015) The Epidemiology of Global Micronutrient Deficiencies. Annals of Nutrition and Metabolism, 66, 22-33.

https://doi.org/10.1159/000371618

[7] Michelazzo, F.B., Oliveira, J.M., Stefanello, J., Luzia, L.A. and Rondo, P.H. (2013) The Influence of Vitamin A Supplementation on Iron Status. Nutrients, 5, 4399-4413. https://doi.org/10.3390/nu5114399

[8] Suchdev, P.S., Pena-Rosas, J.P. and De-Regil, L.M. (2015) Multiple Micronutrient Powders for Home (Point-of-Use) Fortification of Foods in Pregnant Women (Re- 
view). Cochrane Database of Systematic Reviews, No. 6, CD011158.

https://doi.org/10.1002/14651858.CD011158.pub2

[9] Haider, B.A. and Bhutta, Z.A. (2017) Multiple-Micronutrient Supplementation for Women during Pregnancy (Review). Cochrane Database of Systematic Reviews, No. 4, CD004905. https://doi.org/10.1002/14651858.CD004905.pub5

[10] Sguassero, Y., de Onis, M., Bonotti, A.M. and Carroli, G. (2012) Community-Based Supplementary Feeding for Promoting the Growth of Children under Five Years of Age in Low and Middle Income Countries. Cochrane Database of Systematic Reviews, No. 6, CD005039.

[11] Arsenaut, J.E and Brown, K.H. (2017) Effects of Protein or Amino-Acid Supplementation on the Physical Growth of Young Children in Low-Income Countries. Nutrition Reviews, 75, 699-717. https://doi.org/10.1093/nutrit/nux027

[12] Gopaldas, T. (2005) Improved Effect of School Meals with Micronutrient Supplementation and Deworming. Food and Nutrition Bulletin, 26, S220-S229. https://doi.org/10.1177/15648265050262S213

[13] Moretti, D., Zimmermann, M.B., Muthayya, S., Thankachan, P., Lee, T.C., Kurpad, A.V. and Hurrell, R.F. (2006) Extruded Rice Fortified with Micronized Ground Ferric Pyrophosphate Reduces Iron Deficiency in Indian Schoolchildren: A Double-Blind Randomized Controlled Trial. The American Journal of Clinical Nutrition, 84, 822-829. https://doi.org/10.1093/ajcn/84.4.822

[14] Winichagoon, P., McKenzie, J.E., Chavasit, V., Pongcharoen, T., Gowachirapant, S., Boonpraderm, A., et al. (2006) A Multimicronutrient-Fortified Seasoning Powder Enhances the Hemoglobin, Zinc, and Iodine Status of Primary School Children in North East Thailand: A Randomized Controlled Trial of Efficacy. The Journal of Nutrition, 136, 1617-1623. https://doi.org/10.1093/jn/136.6.1617

[15] Manger, M.S., McKenzie, J.E., Winichagoon, P., Gray, A., Chavasit, V., Pongcharoen, T., et al. (2008) A Micronutrient-Fortified Seasoning Powder Reduces Morbidity and Improves Short-Term Cognitive Function, but Has No Effect on Anthropometric Measures in Primary School Children in Northeast Thailand: A Randomized Controlled Trial. The American Journal of Clinical Nutrition, 87, 1715-1722. https://doi.org/10.1093/ajcn/87.6.1715

[16] Pinkaew, S., Winichagoon, P., Hurrell, R.F. and Wegmuller, R. (2013) Extruded Rice Grains Fortified with Zinc, Iron, and Vitamin A Increase Zinc Status of Thai School Children When Incorporated into a School Lunch Program. The Journal of Nutrition, 143, 362-368. https://doi.org/10.3945/jn.112.166058

[17] The NEMO Study Group (2007) Effect of a 12-mo Micronutrient Intervention on Learning and Memory in Well-Nourished and Marginally Nourished School-Aged Children: 2 Parallel, Randomized, Placebo-Controlled Studies in Australia and Indonesia. The American Journal of Clinical Nutrition, 86, 1082-1093.

https://doi.org/10.1093/ajcn/86.4.1082

[18] Angeles-Agdeppa, I., Capanzana, M.V., Barba, C.V., Florentino, R.F. and Takanashi, K. (2008) Efficacy of Iron-Fortified Rice in Reducing Anemia among Schoolchildren in the Philippines. International Journal for Vitamin and Nutrition Research, 78, 74-86. https://doi.org/10.1024/0300-9831.78.2.74

[19] Osei, A.K., Rosenberg, I.H., Houser, R.F., Bulusu, S., Mathews, M. and Hamer, D.H. (2010) Community-Level Micronutrient Fortification of School Lunch Meals Improved Vitamin A, Folate, and Iron Status of Schoolchildren in Himalayan Villages of India. The Journal of Nutrition, 140, 1146-1154.

https://doi.org/10.3945/jn.109.114751 
[20] Sazawal, S., Habib, A., Dhingra, U. Dutta, A., Dhingra, P., Sarkar, A., et al. (2013) Impact of Micronutrient Fortification of Yoghurt on Micronutrient Status Markers and Growth-A Randomized Double Blind Controlled Trial among School Children in Bangladesh. BMC Public Health, 13, 514. https://doi.org/10.1186/1471-2458-13-514

[21] Ash, D.M., Tatala, S.R., Frongillo Jr., E.A., Ndossi, G.D. and Latham, M.C. (2003) Randomized Efficacy Trial of a Micronutrient-Fortified Beverage in Primary School Children in Tanzania. The American Journal of Clinical Nutrition, 77, 891-898. https://doi.org/10.1093/ajcn/77.4.891

[22] Abrams, S.A., Mushi, A., Hilmers, D.C., Griffin, I.J., Davila, P. and Allen, L. (2003) A Multinutrient-Fortified Beverage Enhances the Nutritional Status of Children in Botswana. The Journal of Nutrition, 133, 1834-1840. https://doi.org/10.1093/jn/133.6.1834

[23] van Stuijvenberg, M.E., Kvalsvig, J.D., Faber, M., Kruger, M., Kenoyer, D.G. and Benade, A.J. (1999) Effect of Iron-, Iodine-, and Beta-Carotene-Fortified Biscuits on the Micronutrient Status of Primary School Children: A Randomized Controlled Trial. The American Journal of Clinical Nutrition, 69, 497-503. https://doi.org/10.1093/ajcn/69.3.497

[24] Nga, T.T., Winichagoon, P., Dijkhuizen, M.A., Khan, N.C., Wasantwisut, E., Furr, H. and Wieringa, F.T. (2009) Multi-Micronutrient-Fortified Biscuits Decreased Prevalence of Anemia and Improved Micronutrient Status and Effectiveness of Deworming in Rural Vietnamese School Children. The Journal of Nutrition, 139, 1013-1021. https://doi.org/10.3945/jn.108.099754

[25] Hieu, N.T., Sandalinas, F., de Sesmaisons, A., Laillou, A., Tam, N.P., Khan, N.C., et al. (2012) Multi-Micronutrient-Fortified Biscuits Decreased The Prevalence of Anaemia and Improved Iron Status, Whereas Weekly Iron Supplementation Only Improved Iron Status in Vietnamese School Children. British Journal of Nutrition, 108, 1419-1427. https://doi.org/10.1017/S0007114511006945

[26] Iannotti, L.L., Henretty, N.M., Delnatus, J.R., Previl, W., Stehl, T., Vorloper, S., et al. (2015) Ready-to-Use Supplementary Food Increases Fat Mass and BMI in Haitian School-Aged Children. The Journal of Nutrition, 145, 813-822. https://doi.org/10.3945/jn.114.203182

[27] Powell, C.A., Walker, S.P., Chang, S.M. and Grantham-McGregor, S.M. (1998) Nutrition and Education: A Randomized Trial of the Effects of Breakfast in Rural Primary School Children. The American Journal of Clinical Nutrition, 68, 873-879. https://doi.org/10.1093/ajcn/68.4.873

[28] Simeon, D.T. (1998) School Feeding in Jamaica: A Review of Its Evaluation. The American Journal of Clinical Nutrition, 67, 790S-794S. https://doi.org/10.1093/ajcn/67.4.790S

[29] Studdert, L.J., Soekirman, S., Rasmussen, K.M. and Habicht, J.P. (2004) Community-Based School Feeding during Indonesia's Economic Crisis: Implementation, Benefits, and Sustainability. Food and Nutrition Bulletin, 25, 156-165. https://doi.org/10.1177/156482650402500208

[30] Sekiyama, M., Roosita, K. and Ohtsuka, R. (2017) Locally Sustainable School Lunch Intervention Improves Hemoglobin and Hematocrit Levels and Body Mass Index among Elementary Schoolchildren in Rural West Java, Indonesia. Nutrients, 9, 868. https://doi.org/10.3390/nu9080868

[31] Pappas, G., Agha, A., Rafique, G., Khan, K.S., Badruddin, S.H. and Peermohamed, H. (2008) Community-Based Approaches to Combating Malnutrition and Poor 
Education among Girls in Resource-Poor Settings: Report of a Large Scale Intervention in Pakistan. Rural and Remote Health, 8, 820. https://www.rrh.org.au/journal/article/820

[32] Nkhoma, O.W., Duffy, M.E., Cory-Slechta, D.A., Davidson, P.W., McSorley, E.M., Strain, J.J. and O'Brien, G.M. (2013) Early-Stage Primary School Children Attending a School in the Malawian School Feeding Program (SFP) Have Better Reversal Learning and Lean Muscle Mass Growth than Those Attending a Non-SFP School. The Journal of Nutrition, 143, 1324-1330. https://doi.org/10.3945/jn.112.171280

[33] Zeba, A.N., Prevel, Y.M., Some, I.T. and Delisle, H.F. (2006) The Positive Impact of Red Palm Oil in School Meals on Vitamin A Status: Study in Burkina Faso. Nutrition Journal, 5, 5-17. https://doi.org/10.1186/1475-2891-5-17

[34] Grillenberger, M., Neumann, C.G., Murphy, S.P., Bwibo, N.O., Weiss, R.E., Jiang, L., et al. (2006) Intake of Micronutrients High in Animal-Source Foods Is Associated with Better Growth in Rural Kenyan School Children. British Journal of $\mathrm{Nu}^{-}$ trition, 95, 379-390. https://doi.org/10.1079/BJN20051641

[35] Walingo, M.K. and Musamali, B. (2008) Nutrient Intake and Nutritional Status Indicators of Participant and Nonparticipant Pupils of a Parent-Supported School Lunch Program in Kenya. Journal of Nutrition Education and Behavior, 40, 298-304. https://doi.org/10.1016/j.jneb.2008.04.353

[36] Grillenberger, M., Neumann, C.G., Murphy, S.P., Bwibo, N.O., Veer, P., Hautvast, J.G.A.J. and West, C.E. (2003) Food Supplements Have a Positive Impact on Weight Gain and the Addition of Animal Source Foods Increases Lean Body Mass of Kenyan Schoolchildren. The Journal of Nutrition, 133, 3957S-3964S.

https://doi.org/10.1093/jn/133.11.3957S

[37] Neumann, C.G., Jiang, L., Weiss, R.E., Grillenberger, M., Geva, C.A., Siekmann, J.H., et al. (2013) Meat Supplementation Increases Arm Muscle Area in Kenyan Schoolchildren. British Journal of Nutrition, 109, 1230-1240.

https://doi.org/10.1017/S0007114512003121

[38] Neumann, C.G., Bwibo, N.O., Jiang, L. and Weiss, R.E. (2013) School Snacks Decrease Morbidity in Kenyan Schoolchildren: A Cluster Randomized, Controlled Feeding Intervention Trial. Public Health Nutrition, 16, 1593-1604. https://doi.org/10.1017/S1368980013000876

[39] Hulett, J.L., Weiss, R.E., Bwibo, N.O., Galal, O.M., Drorbaugh, N. and Neumann, C.G. (2014) Animal Source Foods Have a Positive Impact on the Primary School Test Scores of Kenyan Schoolchildren in a Cluster-Randomised, Controlled Feeding Intervention Trial. British Journal of Nutrition, 111, 875-886. https://doi.org/10.1017/S0007114513003310

[40] Jomaa, L.H., McDonnell, E. and Probart, C. (2011) School Feeding Programs in Developing Countries: Impacts on Children's Health and Educational Outcomes. Nutrition Reviews, 69, 83-98. https://doi.org/10.1111/j.1753-4887.2010.00369.x

[41] Khor, G.L. and Misra, S. (2012) Micronutrient Interventions on Cognitive Performance of Children Aged 5 - 15 Years in Developing Countries. Asia Pacific Journal of Clinical Nutrition, 21, 476-486. http://apjcn.nhri.org.tw/server/APJCN/21/4/476.pdf

[42] National Institute of Population Research and Training (2016) Bangladesh Demographic and Health Survey 2014. Ministry of Health and Family Welfare, Bangladesh, Dhaka. https://dhsprogram.com/pubs/pdf/FR311/FR311.pdf

[43] Jahan, K. and Hossain, M. (1998) Nature and Extent of Malnutrition in Bangladesh: Bangladesh National Nutrition Survey 1995-96. Institute of Nutrition and Food 
Science, University of Dhaka, Dhaka.

[44] Ahmed, F. (2000) Anaemia in Bangladesh: A Review of Prevalence and Aetiology. Public Health Nutrition, 3, 385-393. https://doi.org/10.1017/S1368980000000446

[45] Jamil, K.M., Rahman, A.S., Bardhan, P.K., Khan, A.I., Chowdhury, F., Sarker, S.H., et al. (2008) Micronutrients and Anaemia. Journal of Health, Population and Nutrition, 26, 340-355.

https://www.ncbi.nlm.nih.gov/pmc/articles/PMC2740705/pdf/jhpn0026-0340.pdf

[46] International Centre for Diarrhoeal Diseases Research, Bangladesh (ICDDR, B), Global Alliance for Improved Nutrition (GAIN), The United Nations Children's Fund (UNICEF), Institute of Public Health and Nutrition (IPHN) (2013) National Micronutrients Status Survey 2011-12. Center for Nutrition and Food Security, Dhaka, Bangladesh,

https://staticl.squarespace.com/static/56424f6ce4b0552eb7fdc4e8/t/57490d3159827 e39bd4d2314/1464405328062/Bangladesh_NMS_final_report_2011-12.pdf

[47] Ahmed, F. (1999) Vitamin A Deficiency in Bangladesh: A Review and Recommendations for Improvement. Public Health Nutrition, 2, 1-14.

https://doi.org/10.1017/S1368980099000014

[48] Downen, J., Finan, T., Gomes, M. and Walters, N.S. (2011) School Feeding in Bangladesh (2001-2009): A Mixed Method Impact Evaluation Vol I. Full Report. World Food Programme, Dhaka, Bangladesh.

http://documents.wfp.org/stellent/groups/public/documents/reports/wfp241997.pdf ?_ga=2.179841060.100673288.1510466794-1370007068.1510466794

[49] Lee, V., Ahmed, F., Wada, S., Ahmed, T., Ahmed, A.M.S., Banu, C.P. and Akhter, N. (2008) Extent of Vitamin A Deficiency among Rural Pregnant Women in Bangladesh. Public Health Nutrition, 11, 1326-1331. https://doi.org/10.1017/S1368980008002723

[50] Ahmed, T., Mahfuz, M., Ireen, S., Ahmed, A.M.S., Rahman, S., Islam, M.M., et al. (2012) Nutrition of Children and Women in Bangladesh: Trends and direCtions for the Future. Journal of Health, Population and Nutrition, 30, 1-11. https://doi.org/10.3329/jhpn.v30i1.11268

[51] Mark, H.E., Houghton, L.A., Gibson, R.S., Monterrosa, E. and Kraemer, K. (2016) Estimating Dietary Micronutrient Supply and the Prevalence of Inadequate Intakes from National Food Balance Sheets in the South Asia Region. Asia Pacific Journal of Clinical Nutrition, 25, 368-376. http://apjcn.nhri.org.tw/server/APJCN/25/2/368.pdf

[52] Arsenault, J.E., Yakes, E.A., Islam, M.M., Hossain, M.B., Ahmed, T., Hotz, C., et al. (2013) Very Low Adequacy of Micronutrient Intakes by Young Children and Women in Rural Bangladesh Is Primarily Explained by Low Food Intake and Limited Diversity. The Journal of Nutrition, 143, 197-203.

https://doi.org/10.3945/jn.112.169524

[53] UNICEF (2016) The State of the World's Children 2016. UNICEF, New York. https://www.unicef.org/publications/files/UNICEF_SOWC_2016.pdf

[54] Ahmed, A.U. (2004) Impact of Feeding Children in School: Evidence from Bangladesh. International Food Policy Research Institute, Washington DC.

http://ebrary.ifpri.org/utils/getfile/collection/p15738coll2/id/126329/filename/12654 0.pdf

[55] WHO/FAO/UNU (2007) Protein and Amino Acid Requirements in Human Nutrition: Joint WHO/FAO/UNU Expert Consultation. WHO Technical Report Series No. 935, WHO, Geneva, Switzerland. http://apps.who.int/iris/bitstream/10665/43411/1/WHO_TRS_935_eng.pdf?ua=1 
[56] University of Dhaka, Institution of Nutrition and Food Science (1992) Recommended Dietary Allowances for Bangladesh People, in Food Composition Table Bangladesh. University of Dhaka, Dhaka, Bangladesh. (In Bangladesh)

[57] Lohmann, T.G., Roche, A.F. and Martorell, R. (1988) Anthropometric Standardization Reference Manual. Human Kinetics Books, Illinois.

[58] WHO (2007) Growth Reference Data for 5 - 19 Years. WHO, Geneva, Switzerland. http://www.who.int/growthref/en/

[59] WHO (2001) Iron Deficiency Anemia, Assessments, Prevention and Control: A Guide for Programme Managers, WHO/NHD/01.3. WHO, Geneva, Switzerland. http://apps.who.int/iris/bitstream/10665/66914/1/WHO_NHD_01.3.pdf?ua=1

[60] WHO/FAO (2004) Vitamin and Mineral Requirements in Human Nutrition. World Health Organization, Geneva, Switzerland.

[61] International Zinc Nutrition Consultative Group (IZiNCG), Brown, K.H., Rivera, J.A., et al. (2004) International Zinc Nutrition Consultative Group (IZiNCG) Technical Document \#1. Assessment of the Risk of Zinc Deficiency in Populations and Options for Its Control. Food and Nutrition Bulletin, 25, S99-S203.

[62] Best, C., Neufingerl, N., Del Rosso, J.M., Transler, C., van den Briel, T. and Osendarp, S. (2011) Can Multi-Micronutrient Food Fortification Improve the Micronutrient Status, Growth, Health, and Cognition of Schoolchildren? A Systematic Review. Nutrition Reviews, 69, 186-204.

https://doi.org/10.1111/j.1753-4887.2011.00378.x

[63] Ramakrishnan, U., Aburto, N., McCabe, G. and Martorell, R. (2004) Multimicronutrient Interventions but Not Vitamin a or Iron Interventions Alone Improve Child Growth: Results of 3 Meta-Analyses. The Journal of Nutrition, 134, 2592-2602. https://doi.org/10.1093/jn/134.10.2592

[64] Merrill, R.D., Shamim, A.A., Ali, H., Labrique, A.B., Schulze, K., Christian, P. and West, K.P. (2012) High Prevalence of Anemia with Lack of Iron Deficiency among Women in Rural Bangladesh: A Role for Thalassemia and Iron in Groundwater. Asia Pacific Journal of Clinical Nutrition, 21, 416-424. http://apjcn.nhri.org.tw/server/APJCN/21/3/416.pdf

[65] Rahman, S., Ahmed, T., Rahman, A.S., Alam, N., Ahmed, A.M.S., Lreen, S., et al. (2016) Determinants of Iron Status and HB in the Bangladesh Population: The Role of Groundwater Iron. Public Health Nutrition, 19, 1862-1874. https://doi.org/10.1017/S1368980015003651

[66] Bhargava, A., Bouis, H.E. and Scrimshaw, N.S. (2001) Dietary Intakes and Socioeconomic Factors Are Associated with the Hemoglobin Concentration of Bangladeshi Women. The Journal of Nutrition, 131, 758-764.

https://doi.org/10.1093/jn/131.3.758

[67] Andersen, A.B., Schmidt, L., Faurholt-Jepsen, D., Roos, N., Friis, H., Kongsbak, K., et al. (2016) The Effect of Daily Consumption of the Small Fish Amblypharyngodon mola or Added Vitamin A on Iron Status: A Randomised Controlled Trial among Bangladeshi Children with Marginal Vitamin A Status. Asia Pacific Journal of Clinical Nutrition, 25, 464-471. http://apjcn.nhri.org.tw/server/APJCN/25/3/464.pdf

[68] Das, J.K., Salam, R.A., Kumar, R. and Bhutta, Z.A. (2013) Micronutrient Fortification of Food and Its Impact on Woman and Child Health: A Systematic Review. Systematic Reviews, 2, 67. https://doi.org/10.1186/2046-4053-2-67

[69] Ahmed, F., Khan, M.R., Akhtaruzzaman, M., Karim, R., Williams, G., Toresse, H., et al. (2010) Long-Term Intermittent Multiple Micronutrient Supplementation Enhances Hemoglobin and Micronutrient Status More than Iron + Folic Acid Sup- 
plementation in Bangladeshi Rural Adolescent Girls with Nutritional Anemia. The Journal of Nutrition, 140, 1879-1886. https://doi.org/10.3945/jn.109.119123

[70] Wu, G. (2016) Dietary Protein Intake and Human Health. Food \& Function, 7, 1251-1265. https://doi.org/10.1039/C5FO01530H 